\title{
O lugar de quem fala ou sobre a autoria e o tempo
}

\author{
Kleiton de Sousa Moraes ${ }^{1 *}$ \\ ${ }^{1}$ Universidade Federal do Ceará, Fortaleza, Ceará, Brasil
}

\section{RESUMO}

A construção de autoridade sobre textos impressos passa pelo processo de distinção do nome em determinado regime de escrita. Acompanhando a trajetória do modinheiro e poeta $\mathrm{Ca}$ tulo da Paixão Cearense, o artigo debate as estratégias mobilizadas pelo escritor a fim de tornar-se autor de sua obra e poeta de destaque no campo literário brasileiro da primeira metade do século XX. A historicidade das práticas de escrita de um "outro" que é dado a ver no texto - o sertanejo popular — é fundamental para a compreensão da representação de uma autoria construída pelo poeta em sua obra. O caráter autoral da obra de Catulo é progressivamente consolidado a partir de um reconhecimento das regras que regem o regime de escrita e de uma trajetória incomum no mundo letrado de então.

Palavras-chave: autoria; representaçôes; literatura; práticas letradas; história.

\section{The Place of those who Speak or on Authorship and Time}

\section{ABSTRACT}

Building authority over printed text goes through the process of distinguishing the name in a given writing regime. Following the trajectory of ditty writer and poet Catulo da Paixão Cearense, the article discusses the strategies mobilized by the writer in order to become the author of his works and a prominent poet in the Brazilian literary of the first half of the $20^{\text {th }}$ century. The historicity of writing practices of an "other" that revealed in the text - the popular hillbilly - is fundamental to understanding the representation of an authorship built by the poet in his works. The authorial character of Catulo's works is progressively consolidated through the recognition of the rules that govern the writing system and this unusual trajectory in the cultured world of that time.

Keywords: authorship; representations; literature; cultured practices; history.

* Professor da Universidade Federal do Ceará. E-mail: kleiton.ufc@gmail.com. 


\section{El lugar de quien habla o sobre la autoría y el tiempo}

\section{RESUMEN}

La construcción de autoridad sobre textos impresos pasa por el proceso de distinción del nombre en determinado régimen de escrita. Acompañando la trayectoria del tonadillero y poeta Catulo da Paixão Cearense, el artículo debate las estrategias movilizadas por el escritor con el fin de tornarse autor de su obra y poeta de destaque en el campo literario brasileńo de la primera mitad del siglo XX. La historicidad de las prácticas de escritura de un "otro" que es dado a ver en el texto - el paleto popular- es fundamental para la comprensión de la representación de una autoría construida por el poeta en su obra. El carácter autoral de la obra de Catulo es progresivamente consolidado a partir de un reconocimiento de las reglas que rigen el régimen de la escritura y de una trayectoria inusual en el mundo letrado de entonces. Palabras clave: autoría; representaciones; literatura; prácticas letradas; historia.

Há vozes que, se destrinchadas a partir de seus ecos, conduzem o ouvinte a uma voz original, ao momento primeiro da palavra viva, à palavra-palavra. Mas essa experiência de pesquisa pela escuta nem sempre conduz, invariavelmente, a um lugar de origem ou a um ponto de onde se desdobraria um indivíduo único, possuidor indelével da singularidade de sua voz. Nesse momento é com espanto que surge a constatação de que, por vezes, o indivíduo que fala não é o sujeito falante. Dito de outra maneira, nem sempre o sujeito falante se subtrai ao corpo do indivíduo de onde se fala. Esse desencontro entre corpo e voz desloca, de maneira incômoda, um pesquisador humanista, que vê no encontro entre voz e corpo o espaço de autonomia última do sujeito em sua liberdade sobre aquilo que diz. Para este último, a voz constitui, sob todos os monopólios reivindicados para se ser livre, o último reduto a ser conquistado, a fortaleza indestrutível do indivíduo em sua singularidade, de modo que é impossível, nesse ponto, não encontrar na fala a constituição do indivíduo em sujeito. Porém, estranhamente, esse encontro nem sempre pode se dar. Não por uma força exterior que sequestra a voz do indivíduo, mas pelo próprio indivíduo que sequestra a si mesmo fazendo, por um momento, falar-se por outro.

Michel Foucault talvez tenha sido aquele que melhor sistematizou a questão quando se propôe a pensar a pergunta: “Que importa quem fala?”. Michel de Certeau, por sua vez, foi aquele que mais dramatizou a experiência de confrontação de um indivíduo com um Outro que não se diz, mas que se deixa dizer. Confronta-se com a ideia insuportável de encontrar na singularidade inescapável de um indivíduo, que fala, a voz de um Outro que não está. ${ }^{1}$

\footnotetext{
${ }^{1}$ Tais reflexôes foram desenvolvidas pelos autores em pelo menos dois livros: FOUCAULT, Michel. O que
} 
Embora, em geral, escape da crítica moderna o estatuto de construção de um discurso a partir de um indivíduo, o regime que ainda governa muitas das produçóes literárias contemporâneas é a de identificação daquilo que se diz (e que se escreve) sob um nome próprio. E aí se chegam a rápidas conclusóes, como a que trata de reivindicar a propriedade irrefutável do sujeito sob seu objeto, seja ele voz ou escrita. Naquele identificado como artista, essa linearidade se torna quase um imperativo. Ora, quem há de negar o caráter de propriedade (de monopólio autoral, digamos) de uma produçáo artística vinda à luz sob um nome próprio de alguém que comprovadamente existe? Mas essa equação, que, a priori, parece fatal, nem sempre se consuma.

Na modernidade, a autoria sobre determinado produto passa pela reivindicação jurídica de sua posse. $\mathrm{O}$ procedimento de burocratização da criação definiu o momento de posse num acontecimento procedural, fazendo esquecer o processo de produção da autoria e, por fim, tornando evidente o autor do produto. Esse mecanismo de apagamento da historicidade da produção conduz à criação do gênio, envolto em uma representação social distinta de seus pares mundanos. Esse envolvimento entre afirmação autoral e consequente identificação de uma genialidade no sujeito-autor não se dá de maneira automática, ao contrário: há um processo de construção autoral que pode negar ao sujeito que escreve a autoria ou, dito de outra forma, nem todo escritor é autor de sua obra e, algo insuportável no domínio literário, nem todo gênio é aquele que escreveu a obra genial que se diz autor. Por vezes, confundir-se com aquele que escreve pode negar a autoria, e, em outras vezes, para afirmação do gênio literário de um indivíduo, é melhor nem escrever. ${ }^{2}$

No Brasil, a biografia exemplar ainda absorve grande parte da produção de reflexóes que pautam uma trajetória autoral. O "nome próprio" muitas vezes ganha as prateleiras

é um autor? In: FOUCAULT, Michel. Ditos e escritos. Estética: literatura e pintura, música e cinema. Rio de Janeiro: Forense Universitária, 2009, v III; CERTEAU, Michel de. La Fabula Mistica. Siglos XVI-XVII. México: Universidad Iberoamericana, 2004.

${ }^{2}$ Há uma vasta bibliografia que debate o papel da autoria na história - em grande parte tais estudos foram impulsionados pelas reflexóes de Michel Foucault, na famosa conferência intitulada "O que é o autor?". Dentre estes, cabe destacar as reflexôes do historiador francês Roger Chartier em pelo menos três publicaçôes: CHARTIER, Roger. O que é um autor: revisão de uma genealogia. São Carlos: Ufscar, 2012; CHARTIER, Roger. A ordem dos livros. Brasília: UNB, 1996; CHARTIER, Roger. Autoria e história cultural da ciência. Rio de Janeiro: Azougue Editorial, 2013. Os trabalhos de Martha Woodmansee são de grande utilidade para a compreensão dos mecanismos de construção da autoria na modernidade: WOODMANSEE, Martha. On the author effect: recovering collectivity. In: WOODMANSEE, Martha; Jaszi, Peter (Ed.). The Construction of Authorship. Textual Appropriation in Law and Literature. Durham e London: Duke University Press, 1994, p. 15-28. Para uma análise da relação entre copyright e genialidade: WOODMANSEE, Martha. The Genius and the Copyright: Economic and Legal Conditions of the Emergence of the Author. EighteenthCentury Studies, v. 17, n. 4, p. 425-448, 1984. A historicidade das práticas de construção de um nome distinto nos meios literários tem estudos competentes, dos quais cabe destacar os excelentes trabalhos de Abel Barros Baptista e João Adolfo Hansen: BAPTISTA, Abel Barros. A formação do nome. Campinas: Editora Unicamp, 2003; HANSEN, João Adolfo. Autor. In: JOBIM, José Luís (Org.). Palavras da crítica. Rio de Janeiro: Imago, 1993. 
com best-sellers biográficos de emulação, onde a genialidade e a trajetória incomum ganham mais espaço que a reflexão crítica. A consolidação de uma vida distinta se sobrepóe à "humanidade" do indivíduo. Na produção historiográfica, o temor por encarar o "nome" segue uma receita que teme pela escrita que possa evocar as fórmulas das velhas biografias. Ademais, no campo da literatura - espaço de consagração do sujeito em diversos locais do Ocidente —, a produção de um cânone teimava, havia pouco tempo, em apagar a pesquisa que introduzisse o papel do editor e leitor no âmago da produçáo do texto do autor consagrado. Daí, da análise crítica da historicidade dos textos, os novos pesquisadores que tentavam fugir do cânone buscaram antes proceder à análise crítica da historicidade do cânone. Os críticos literários Paulo Franchetti, Alcir Pécora, Abel Barros Baptista e João Adolfo Hansen são quatro dos nomes mais importantes que vem lançando mão desse tipo de crítica, sobretudo ao pensar a necessidade de fuga a certo "paradigma nacional" que orienta as leituras de textos produzidos no Brasil - cuja mais consagrada produção é $A$ formação da literatura brasileira, de Antonio Candido. ${ }^{3}$ A partir de seus trabalhos, puderam surgir novos problemas para se trabalhar com textos no Brasil, e com eles nomes pouco reconhecidos por uma "História da Literatura", como Luiz Murat, Benjamin Costallat e Catulo da Paixão Cearense - escritores consagrados no campo literário brasileiro de inícios do século XX.

\section{Catulo da Paixão Cearense, ou, como se constrói um autor?}

No Brasil do começo do século XX, parte da elite letrada se mobilizou na produção de uma escrita que tinha como tema dileto a ideia de construção de uma nacionalidade que, por sua vez, passava por um melhor conhecimento do "povo". A demanda antiga pela construção de uma nacionalidade brasileira ganhava novo fôlego com o advento da República, e a temática de conhecer o "povo" seguia o mesmo caminho. Nesse momento, o campo literário brasileiro viu o amanhecer de uma produção que em todas as etapas de sua produção reivindicava o status de "popular". Tornou-se algo comum a publicidade de um livro vir com a adjetivação de "popular" e, dentre os temas populares, o "sertão" foi, sem dúvida, alçado a tema principal - muito devido ao sucesso da obra de Euclides da Cunha, Os sertóes, publicada em 1902. Essa febre pelas coisas sertanejas alimentava não só a literatura, mas os pró-

\footnotetext{
${ }^{3}$ Para um primeiro conhecimento das reflexôes críticas desses autores, cf: FRANCHETTI, Paulo. Estudos de Literatura brasileira e portuguesa. Cotia: Ateliê Editorial, 2007; PÉCORA, Alcir. Máquina de gêneros. São Paulo: Edusp, 2001; BAPTISTA, Abel Barros. O livro agreste. Campinas: Unicamp, 2005; HANSEN, João Adolfo. Reorientaçóes no campo da leitura literária. In: ABREU, Márcia; SCHAPOCHNIK, Nelson (Orgs.). Cultura letrada no Brasil: objeto e práticas. Campinas: Mercado de Letras, ALB/ São Paulo: Fapesp, 2005, p. 13-44.
} 
prios estudos científicos, que viam na emergência de se conhecer o sertão — de dá-lo a ver de forma científica — uma missão do conhecimento que se queria interventor na sociedade. ${ }^{4}$ A "moda" por coisas ditas do "povo" se expressava em qualificaçóes de livrarias e editoras (era conhecida a Livraria Quaresma, denominada também de Livraria Popular, que publicava livros ditos “populares”), na identificação do escritor de livros (Leonardo Motta, Euclides da Cunha e Alberto Rangel, por exemplo, foram alguns que se debruçaram em representar o chamado "povo do sertão" e assim receberam a alcunha de "popular) e na temática a ser publicizada para o grande público, uma vez que vender um livro que contava o "popular" poderia render desde o início ao editor e escritor da obra uma publicidade de sucesso. Essas produçôes, por sua vez, alimentavam a sede pelo "povo", que se expressava no impulso para o seu conhecimento empírico com as lentes da ciência ou descambava para apresentaçóes de exotismos risíveis nos salóes das elites letradas.

$\mathrm{Na}$ esteira do sucesso dos temas "populares", a cada instante surgia um novo artista ou escritor que se arvorava como profundo conhecedor da "alma do povo". Os mecanismos de distinção dessas produçôes eram muitos, porém falar sobre o "povo" com propriedade não era privilégio de qualquer um. Conseguir a autoridade para falar sobre era um requisito básico. Assim, as autorizaçóes eram dadas para aqueles indivíduos inseridos em determinados grupos que lhe davam uma representação social distinta na sociedade (um cientista, por exemplo, ou um escritor já aclamado pelo grande público). O maranhense Catulo da Paixão Cearense foi um desses autores. ${ }^{5}$ As ferramentas de construção de autoridade que mobilizou para ser entendido como um conhecedor das "coisas do povo" são significativas desse processo de reconhecimento social.

Conhecido como modinheiro, Catulo já publicava pela Livraria Quaresma cançóes que se ouviam nas ruas do Rio de Janeiro desde fins do século XIX. Ao apropriar-se do material oral e publicá-los em textos, Catulo arvorava-se como autor desse tipo de produção e aos poucos foi reconhecido como um letrado, pois era autor de livros. Isso autorizou a entrada de Catulo nos salóes da elite letrada carioca, que comumente o chamava para ouvi-lo tocando as modinhas mais conhecidas do Rio de Janeiro acompanhado ao violão. Em 1914, uma de suas cançôes, a toada "Luar do Sertão", fez sucesso no carnaval carioca. ${ }^{6}$ Dali em diante, Ca-

\footnotetext{
${ }^{4}$ A socióloga Nísia Trindade faz um apanhado de como esse impulso de construir a naçáo alça o tema sertanejo como objeto de práticas diversas, que perpassam desde a literatura até os estudos científicos. In: LIMA, Nísia Trindade. Um sertão chamado Brasil. Rio de Janeiro: Revan: Iuperj/Ucam, 1999.

${ }^{5}$ Em geral pouco conhecido do grande público leitor da chamada "Literatura Brasileira", Catulo recebeu esparsas notas em estudos a ela consagrados. Mais evidência, porém, ganha no trabalho do antropólogo Hermano Vianna, "O mistério do samba", onde é entendido pelo estudioso como um "mediador", qual seja, aquele que faz uma espécie de "ponte" entre uma "cultura letrada" e o "povo". Cf. VIANNA, Hermano. $O$ mistério do samba. Rio de Janeiro: Zahar/Ed. UFRJ, 2010.

${ }^{6}$ Há uma famosa controvérsia acerca da autoria da cançáo "O Luar do Sertão". Catulo seria posteriormente acusado de se apropriar de um material oral que não era de sua criação. Assim, o violonista João Pernambuco seria o verdadeiro autor da música. Essa polêmica teria se expressado num debate vindo a público em meados dos anos 1940, que contou com a participação dos compositores Almirante e Heitor Villa-Lobos. Sobre tal controvérsia o próprio Catulo se manifestou diversas vezes. Cf. BARBOSA, Francisco de Assis; SILVEIRA,
} 
tulo deixaria de publicar modinhas - vista como uma produção menor diante do também tema popular "sertâo" já consagrado no meio literário — para publicar poemas sertanejos. Além do mais, deixava de publicar pela Livraria Quaresma - uma livraria conhecida por ser demais "popular", com suas publicaçôes voltadas para o grande público que iam desde livretos de modinhas até manuais de namoro —, para publicar pela "séria" Livraria Castilho.

Escolher escrever sobre o sertáo não era algo inédito no período, uma vez que havia uma profusão de escritores que apareciam a cada esquina, ávidos de embarcar na moda de contar sobre o sertão. Impulsionado por conhecidos letrados de então - que organizaram uma festa no Teatro S. Pedro a fim de arrecadar dinheiro para a publicação de seu livro de estreia em temas sertanejos ${ }^{7}$ - Catulo da Paixáo Cearense procuraria um caminho distinto para sobressair-se diante de outras publicaçóes.

Quando, em setembro de 1918, publicou seu primeiro livro de poemas sertanejos, Meu sertão, Catulo o construiu a partir de uma forma incomum no mundo literário brasileiro: os poemas eram a transcrição da fala de um sertanejo. $\mathrm{O}$ novo poeta se apropriava de um tipo de escrita da oralidade que era identificada, já àquela época, com a fala de poetas populares do nordeste do país, publicada comumente nos já conhecidos livretos de cordel. O referente oral é supostamente transferido para o impresso ipsi litteris de forma que um leitor possa escutar, na sonoridade das palavras e dos versos lidos, a "voz sertaneja":

Nosso sinhô dê bons dia
a vasmincê, meu patrão,
e a toda a sua famía

Cheguei há cinco sumana nesta grande capitá.

Sou musgo!... Musgo gaitêro!...

E, não é prú me gabá

fui o terrô dos violeiro

dos sertâo do Ceará ${ }^{8}$

Joel. Os homens não falam de mais. Rio de Janeiro: Editora Alba, 1942.

${ }^{7}$ A iniciativa do evento partiu do jovem advogado Assis Chateaubriand, que, para tanto, formou uma "Comissão Central de Homenagem a Catulo" incluindo nomes os mais distintos da sociedade carioca naqueles tempos, entre os quais os membros da Academia Brasileira de Letras (ABL), Mário de Alencar e João do Rio. Na plateia estavam homens conhecidos na época, como Pandiá Calógeras, então o ministro da Fazenda, e o jornalista Roquete Pinto. Para os eventos contados, Cf. CEARENSE, Catulo da Paixão. Meu sertão. Rio de Janeiro: Livraria Castilho, 1918, p. 17-22. Sobre a programaçáo daquela noite no Teatro São Pedro, Cf. O Pais. 12 set. 1918, p. 5.

${ }^{8}$ CEARENSE, Catulo da Paixão. Meu sertão, op. cit., p. 39. 
Assim, consumada a escrita e construído um personagem "sertanejo", Catulo, ele mesmo, que morou por um pequeno período no sertão do Ceará e, importante, sendo identificado nominalmente como um deles - afinal, carregava em seu nome próprio um "cearense", o que lhe dava uma identificação imediata - , poderia, dessa maneira, ser reconhecido como um "poeta do sertão". O círculo se fecha, de modo a não restar dúvida de que, a partir de todo esse esquema traçado, a identificaçáo do autor com seu personagem conduzisse Catulo ao panteão de um poeta diferente de todos os outros que tematizavam o sertáo naquele período: ele seria, pela própria coincidência biográfica, o próprio povo do sertão. Mas se, em suas estratégias para ser reconhecido como poeta, todos os elementos já mencionados não foram negligenciados por Catulo, eles em si não explicariam o fato de o autor nunca se identificar como um "popular" e, paradoxalmente, querer ser lido como um melhor conhecedor do "popular". Daí sua incessante busca por ser representado como alguém conhecedor das "boas letras": "Embora conheça bem a métrica, tanto que vou publicar um livro de poesias traduzidas, prefiro estabelecer esse consórcio entre a melodia e a poesia."

Catulo negava sua posição de iletrado no mesmo momento em que buscava se expressar como tal. Essa ambiguidade só pôde se dar pela evocação de um terceiro personagem, entre Catulo e o popular-sertanejo, que dava a autenticidade para a sua poesia e que ele representava, como sendo uma nova vida, a alma: "Quando escrevo os meus versos, sinto que minha alma se eleva, que uma nova vida se estua pelo corpo."10

Apresentando Meu sertão aos leitores de Catulo, os escritores Humberto de Campos e Alberto D’Oliveira transmitem uma primeira impressão do livro explicando o estranho fato de aparecer ali uma linguagem rústica:

Catulo não quer, porém, que os seus frutos nasçam no jardim ou brilhem em vasos de porcelana: quer conservá-los no mato, envoltos nas folhas. A seiva para o fruto quem dá é Deus. À árvore compete, apenas, dar forma ao pomo. Catulo tem toda inspiração dos grandes e verdadeiros poetas; e como é sertanejo, vaza essa forte seiva nos rústicos moldes que lhe fornece o sertão. ${ }^{11}$

A analogia com a árvore não é gratuita. $\mathrm{O}$ escritor tenta estabelecer um espaço distinto para a recepção de Catulo por meio do uso da analogia para explicar ao leitor que a poesia ali publicada não era propriamente de Catulo. Este daria a forma. Competia ao autor a expressão de algo anterior a ele mesmo, que não é só dele, não se subtrai a ele, mas que se expressa melhor nele: o povo. Seu texto é evento, é acontecimento efêmero, de algo sem tempo, que veio antes dele:

\footnotetext{
${ }^{9}$ Entrevista ao jornal O Pais, 25 fev. 1906, p. 6.

${ }^{10}$ Idem.

${ }^{11}$ CAMPOS, Humberto de. Homenagem a Catulo Cearense. In: CEARENSE, Catulo da Paixão. Meu sertão, op. cit., p. 19.
} 
(...) poeta bravio, poeta cujos versos não foi preciso semear e ainda menos cultivar, poeta igualmente entendido e apreciado pelos sábios e pelos ignorantes, poeta do povo e da raça, poeta e só poeta, que só pode dar poesia, como as abelhas só podem dar mel. ${ }^{12}$

Havia uma não coincidência temporal de Catulo com a poesia que ele escrevera. $\mathrm{O}$ poema o antecedia. Catulo só o expressava na escrita. Para seus prefaciadores, isso se afirmava no fato de que ele não precisava "semear" e "cultivar", pois era "poeta do povo e da raça", de modo que dele só poderia se extrair tal tipo de poesia, tal qual, inescapavelmente, a abelha que só dá mel. Aqui cada palavra é reveladora. A aproximação desinteressada de Catulo com uma produção que leva seu nome era um fato em conformidade com o que ele era, ou seja, um poeta da raça. "Semear" e "cultivar" seriam trabalhos reservados para outros tipos de poetas, porque na poesia de Catulo “(...) não há elaboração de raciocínio, nem análise; há transbordamento de sensaçóes de sentidos que viveram concretamente a vida da natureza". ${ }^{13}$

Esse afastamento do nome de Catulo do momento de origem da sua poesia era entendido, inclusive, como indissociável para a compreensão da forma como os poemas eram apresentados na publicação. Mesmo Meu sertão trazendo a novidade da escrita de uma suposta oralidade sertaneja no texto, nessas mesmas poesias, é necessário salientar, o personagem principal não podia ser identificado ao próprio Catulo. Por causa disso, o próprio Catulo apresentava-os ao seu leitor, como fez com o personagem Quinca-Micuá:

Não! Lê-de com dor, com mágoa,

essa história, essa romança

de um homem feito creança

esse "Quinca Micuá",

alma pura nobre e santa,

como uma flor redolente,

que, talvez, tão inocente,

não exista outra por cá ${ }^{14}$

Os personagens são revelados nos poemas e, aos poucos, vão surgindo os donos das vozes que Catulo faz aparecer no seu texto: Quinca Micuá, o gaiteiro do sertão; o marroeiro; o lenhador; Chico Mironga, o passador de gado; o vaqueiro; o cangaceiro e o violeiro Chico Mindello. Até aí nada incomum. A diferença aqui está na possível e inevitável associação, pelo leitor, do nome Catulo da Paixão Cearense com os seus personagens representados no

\footnotetext{
${ }^{12}$ D’OLIVEIRA, Alberto. Catulo Cearense. In: CEARENSE, Catulo da Paixão. Meu sertão, op. cit., p. 13. ${ }^{13}$ ALENCAR, Mário de. A poesia de Catulo. In: CEARENSE, Catulo da Paixão. Sertão em flor. Rio de Janeiro: Livraria Castilho, 1919, p. XIII.

${ }^{14}$ CEARENSE, Catulo da Paixão. Em caminho do sertão. In: CEARENSE, Catulo da Paixão. Meu sertão, op. cit., p. 34 .
} 
texto. Uma vez que estes expressavam uma suposta "alma sertaneja” e, sendo Catulo, já havia algum tempo, conhecido como poeta sertanejo, apresentando-se em alguns locais, inclusive, vestido tal e qual, a coincidência entre Catulo, seus personagens e a "alma sertaneja" que ali expressava era inevitável para o leitor daquela época. Catulo era muitas vezes representado como sendo, ele mesmo, o sertanejo de suas poesias.

Mas, ao passo em que era apresentado como um autêntico poeta sertanejo, Catulo buscava estrategicamente afastar-se de toda representação que o poderia identificá-lo tão somente como um dos seus personagens. No poema "Em caminho do sertão", que apresenta o livro Meu sertão, Catulo dirige-se diretamente a seus leitores:

Tenho lido, desde Homero, tudo o que se tem escrito em versos de ouro e granito, de impecável perfeição, mas, talvez, seja ignorância, às vezes fico pasmado com um verso imetrificado de um Manoel Riachão!!! ${ }^{15}$

Um poeta que faz aparecer personagens em seus livros para serem identificados como sertanejos e que, ao mesmo tempo, procura apresentar-se como alguém que lê Homero. Ou melhor: como alguém que não pode ser confundido com seu personagem iletrado. Um letrado que fica "pasmado" com o verso imetrificado do seu personagem Manoel Riachão — que não é e nem pode ser Catulo. Este o expressa - e até se assusta com ele, mas Catulo não o é e, embora seja apresentado em seus prefácios por homens distintos das letras brasileiras e portuguesas do período tal qual um sertanejo, Catulo nega a representação de um sertanejo iletrado para si.

O que se póe no centro da discussão é o caráter da invenção. Catulo assume um tipo de invenção que se dá a partir de uma tradução. Ele é, em última instância, o indivíduo que se apresenta como um escolhido para expressar algo anterior a ele. Essa anterioridade, por outro lado, poderia ser taxada de "antigo", "velho", "bárbaro". Um tempo outro que se expressa no texto.

Monteiro Lobato, por exemplo, vai colocar em xeque a literatura produzida por Catulo por caracterizá-la como a expressão de um barbarismo da língua - o que travaria, inclusive, a ascensão do autor a "grande poeta". Atento a essa controvérsia, o editor dos livros de Catulo, Antônio Castilho, parecia procurar nesse paradoxo um irresistível caminho para apresentar o autor como um poeta distinto de todos os outros. No segundo livro de

${ }^{15}$ Ibidem, p. 35 . 
poemas sertanejos de Catulo, intitulado Sertão em flor, o editor fez surgir duas críticas à poesia de Catulo Cearense: a primeira é a já citada crítica de Monteiro Lobato sobre sua impossibilidade de ser um grande poeta escrevendo num linguajar bárbaro; a segunda crítica era de José Oiticica:

Catulo (...) fez-se, ele mesmo, cangaceiro, marroeiro, lenhador, passador de gado, adotou o semidialeto sertanista com uma justeza raras vezes claudicante. O sabor que nos advém desse processo é delicioso. Seu livro perderia cinquenta por cento se fora escrito em língua de branco. ${ }^{16}$

Embora saltasse aos olhos a discordância dos dois críticos acerca da poesia de Catulo, o editor encontrava um caminho por onde Catulo poderia e deveria ser lido pelo leitor e arrematava dizendo: "CATULO CEARENSE só desejava dar razão aos dois."17

No espaço tênue entre aceitar a crítica de Lobato - que, de resto, chama atenção para as regras que governavam a consagração de um indivíduo a poeta — e, no mesmo movimento, corroborar a crítica elogiosa de Oiticica, que contrastava com a do primeiro, o editor de Catulo via a possibilidade de mostrar ao público leitor a novidade daquela publicação. Para ele, Catulo expressaria em suas publicaçóes a vontade de ser aquilo que Lobato chama de "grande poeta", ao mesmo tempo em que via na representação da fala de seus personagens, que Lobato acreditava ser algo negativo, um fator fundamental para a consagração de Catulo, tal como pensava Oiticica.

Para o editor Castilho, escrever versos num linguajar "bárbaro" era uma opção que Catulo aceitava conscientemente, de bom grado, como um empréstimo da alma do sertanejo, mesmo podendo escrever de maneira mais palatável para o público leitor, ocioso da boa língua:

Embora soubesse e pudesse escrever os seus versos em português vulgar, entendeu Catulo Cearense conservar-lhes a ingenuidade nativa nas palavras rudes e simples, imprevistas e encantadoras, como os diriam os sertanejos, que lhe emprestaram o coração e a alma. ${ }^{18}$

Essa escolha era encarada pelo editor como proposital pelo autor, visando a deixar o "coração" e a "alma” à mostra para seus leitores. Assim, o que avultaria positivamente aos olhos dos leitores do autor seria, ainda, a sua capacidade de expressar-se em outro linguajar. Isso era um sinal de que entre o linguajar e o poema escrito existia o poeta, um "melhor-tradutor" e que este não poderia ser confundido com aquele que ele quer representar, traduzindo.

E qual o lugar distinto e original reservado a Catulo no campo literário no período? Essa questão só fica mais compreensível com a leitura da apresentação do segundo livro de

\footnotetext{
${ }^{16}$ CEARENSE, Catulo da Paixão. Nota prévia. In: CEARENSE, Catulo da Paixão. Sertão em flor, op. cit., p. XX.

${ }^{17}$ Idem.

${ }^{18}$ Idem.
} 
poemas sertanejos de Catulo, Sertão em flor, feita pelo acadêmico Mário de Alencar. Nela, Mário explica a posição de Catulo por meio da evocação de um terceiro:

$\mathrm{Na}$ voz de Catulo canta não a pessoa dele, mas o sertão e o sertanejo. (...) É em suma a alma humana tão vivamente dramatizada (...). Têm-se a impressão de que o poeta náo descreve por palavras, senão as que as próprias cousas e pessoas surgem vivas em imagens da natureza. ${ }^{19}$

A passagem exige uma explicação. Havia uma aproximação entre o Catulo-escritor e os seus personagens, de forma que Catulo poderia facilmente ser identificado como sendo um deles. Embora essa aproximação parecesse ser objeto que atestasse a autenticidade do escritor, estar tão perto assim de seu personagem travaria sua consagraçáo como poeta ser o "maior poeta popular do Brasil", como queria Lobato. A consagração só poderia advir com um afastamento de seu nome dos de seus personagens, porém isso, perigosamente, o afastaria da autenticidade que era evocada também como um fator de distinção em sua produção. Só restava então a saída, que é a de Mário de Alencar, quando propóe que aquilo que era transcrito no texto era Catulo e, ao mesmo tempo, não era. Uma "alma” falaria em Catulo de modo que apenas ele poderia expressar da melhor maneira essa "alma”. Uma alma anterior a Catulo e que ele mesmo, por ser poeta conhecedor das coisas do sertão, era o mais autorizado para traduzir. Na apresentação de Meu sertão, o autor reafirmava essa posição:

Se não traduzo, a contento,

as queixas lá da viola,

uma coisa me consola: -

é contar tudo o que ouvi!

E embora vilipendiado

com inofensível fereza,

pertencer à natureza

desta terra em que nasci. ${ }^{20}$

Catulo levou até as últimas consequências o caráter representacional do acontecimento "escrever", de forma que "quem escreve" é um Outro a partir do escritor. O Outro (a alma) fala nele e ele é a corporificação (o autor, em última instância) de um Outro que está ausente. É a ausência do outro (o sertanejo, o popular) que vai possibilitar a Catulo ser reconhecido como poeta sertanejo, e ele, por sua vez, precisava dessa ausência para construir-se como tal.

\footnotetext{
${ }^{19}$ ALENCAR, Mário de. A poesia de Catulo. In: CEARENSE, Catulo da Paixão. Sertão em flor, op. cit., p. XXI-XXII.

${ }^{20}$ CEARENSE, Catulo da Paixão. Meu sertão, op. cit., p. 28.
} 
Catulo da Paixão Cearense quer ser reconhecido como um autor que expressa o Outro da melhor maneira. Por isso, ele traduz a fala do Outro. É na tradução que reside a função-autor nos seus poemas sertanejos.

Essa ausência da fala do sertanejo, fundamental para a representação de Catulo como alguém que "escreve por", foi constantemente dramatizada no mundo letrado do período, que a via como uma perda irreparável, de modo que a novidade de Catulo poeta sertanejo era a novidade de se conhecer o "verdadeiro povo" em seus livros. É dessa crença na busca de uma "verdade" no texto que Catulo vai se valer para conduzir sua literatura a um êxito final. O caráter de suas poesias sertanejas o colocava no centro de uma comunicação que se fazia povo/elite letrada. E, embora o autor nunca quisesse ser confundido com esse "povo", o momento da escrita, monumentalizado por ele e por seus críticos como sendo o momento performático da alma, era o momento de um Catulo sertanejo que operacionalizava essa comunicação. Ora, a autoridade de um artefato literário começa a se dar quando o indivíduo assume o caráter de invenção do objeto que está escrito, mesmo que este objeto, o texto, expresse uma conformidade tão verossimilhante que, no limite, apague seu autor, ou se confunda com ele. Neste último caso, seu nome parece confundir-se com as coisas que inventa ou conta. Catulo está imerso numa tensão em contar melhor (autor) e ser aquilo que conta (personagem). A saída é a tradução. Catulo assume a tradução como invenção. A tradução que liga um "que não está" para seu leitor.

Se Catulo é tradutor, há de se fazer a pergunta: tradutor de quê? Aí reside a confusão entre "quem escreve" e "quem fala por quem escreve". A autoria que podia ser retirada de Catulo - pela constatação de que, afinal, não há invenção, mas tradução de uma alma logo é reintroduzida por um regime autoral outro, que não é o de "quem escreve", mas de "onde se escreve". E quem escreve, afinal, no caso de Catulo, discorre da cidade. Catulo da Paixão Cearense é apresentado como a autoridade para representar o sertanejo, por já ser um homem citadino. O sertanejo mesmo não poderia ser poeta, pois o interior é uma fase "da infância do mundo", e no interior não há poetas. Mário de Alencar dá disso a melhor explicação em prefácio ao livro de Catulo:

(...) A poesia do homem moderno, em condição progressiva, devera exprimir-se na linguagem da prosa que é a forma própria da análise. Perduraria a expressão simétrica somente em raros poetas, que pudessem ficar alheios à marcha analítica e prosaica do espírito humano, preservando a alma elementar que foi a da infância do mundo, ignorante na ilusão e no sonho do mistério. A sobrevivência da poesia em verso, na maior parte dos que versejam, procede da imitação deleituosa, e em si mesma artística, das formas consagradas da beleza. Por isso subsistem ainda os gêneros, conservados pelo talento a serviço da vontade, por arte aliada à eloquência, por economia do esforço e pelo reflexo inspirador das glórias antigas. ${ }^{21}$

\footnotetext{
${ }^{21}$ ALENCAR, Mário de. A poesia de Catulo. In: CEARENSE, Catulo da Paixão. Sertão em flor, op. cit., p.
} 
Catulo, para Mário de Alencar, faria parte destes últimos, pois seria um daqueles que apareceram "em plena civilização de desencanto, encantados, quase selvagens, extremes de ciência, com os sentidos virginalmente cheios da sensação direta e simples da vida”. ${ }^{22}$ E Mário avançava, articulando o autor com a cidade de forma que "o bem ou mal do Catulo foi seu afastamento do sertão natal", pois seria só na cidade que certo trabalho espiritual poderia se dar:

O trabalho espiritual procede com a condição da dualidade da luz e do som, que não existem sem o meio transmissor: não há luz no vácuo, não há som sem a ondulação do ar ou a vibração de um corpo. A voz do passado só ressoa para o ouvido alheio, próximo ou distante, mas possível, que a esperança realiza.

Agora na cidade havia auditório para escutar o poeta sertanejo; e curiosidade para estimulá-lo. O tema, encurtado em cantigas, dilatou-se em poemas. ${ }^{23}$

Esse trabalho "espiritual" do poeta era corroborado por Mário de Alencar como trabalho empreendido nele (e não só dele), pois: "Tem-se a impressão de que o poeta não descreve por palavras, senão que as próprias cousas e pessoas surgem vivas em imagens da natureza." $\mathrm{Ou}$ em outra passagem: "A pessoa do poeta se desvanece (...) o poeta age inconscientemente sob o domínio da emoção" ${ }^{4}$ ou ainda: "Nesse gênero e com esse talento não existe continuidade de poesia, senão momentos de poesia, que não hão de ser buscados." 25

Mário de Alencar traz à tona a escrita como acontecimento único, como expressáo de uma alma anterior ao poeta, que se vale dele para se comunicar. Daí pensar: "Imagens dessas não se premeditam, não se rebuscam, não se inventam em toda uma vida de espírito; porque nascem por si, sem esforço, são a própria linguagem de quem só percebe por imagem." ${ }^{26}$

"Imagens (...) que não se inventam." É neste ponto que há uma negação positiva da invenção no poeta. Positiva, pois é essa negação da invenção que possibilita a construção de um espaço de tradução autorizada. A inspiração é expressão de algo que já existe. A escrita é o momento reservado para essa expressão e Catulo é, nesse momento único, a alma: "Catulo Cearense é o vate explosivo, emocional, em quem a alma do sertão e da raça brasileira, e sua mestiçagem, faz maravilhosa erupção de sentimentalismo e de sonoridade." ${ }^{27}$

O escritor, na esteira disso, é o gênio autorizado a expressar-se por ser oriundo do sertão, embora não seja um sertanejo. Essa asserção foi necessária para estabelecer o diferencial de

VII-VIII.

${ }^{22}$ Ibidem, p. VIII.

${ }^{23}$ Ibidem, p. XI.

${ }^{24}$ Ibidem, p. X.

${ }^{25}$ Ibidem, p. XI.

${ }^{26}$ Ibidem, p. XIII.

${ }^{27}$ Opiniāo do intelectual Fábio Luz na Revista das Revistas, em 29 de novembro de 1919, em que o editor Castilho fez aparecer em publicação de Catulo. In: CEARENSE, Catulo da Paixão. Matta illuminada. Rio de Janeiro: Livraria Castilho, 1924, p. 282. 
Catulo com outras produçóes do período que se propunham a fazer ver o povo. Para fazer essa distinção, Catulo não poderia ser apresentado como um coletador, um observador, um intelectual do folclore. Sua autoridade não advinha de uma possível autoridade intelectual socialmente referendada por uma pesquisa. Ele não observa, tal qual Sílvio Romero, Melo Moraes, Mário de Andrade ou Afonso Arinos. Ele, na escrita, é o popular sertanejo. Embora, fora desse momento da escrita, não o seja. E é por esse "não ser sertanejo" que pode ser chamado de poeta. Porque, tal como afirma Mário de Alencar, vivendo no sertão, Catulo não seria poeta. $\mathrm{O}$ poeta só existe na cidade. Paixão Cearense é colocado num espaço hierárquico onde é menos do que um intelectual e mais do que um sertanejo. Assertiva esta que fica entendida quando, apresentando em versos, seu livro Meu sertão, ao leitor, Catulo dispara:
Quisera eu ser ignorante,
como um cantor sertanejo!...
Era esse o me desejo!...
Não ter nenhuma instrução,
Mas ter o dom do improviso,
para dizer, de momento,
as dores do pensamento
e as mágoas do coração. ${ }^{28}$

Não ser um sertanejo dava ainda mais a impressão (de resto, instigada por Catulo) de que seus poemas, não sendo invençóes, eram a expressão de um Outro. E ele, por diversas vezes, buscou afastar-se de sua identificação com um sertanejo, exatamente como maneira de se afirmar como poeta:

Eu sou o maior intérprete do sertão

O meu grande mérito está nisso: em não conhecer o sertão e descrevê-lo tão admiravelmente. Por isso é que eu me considero o maior intérprete do sertão do Brasil. ${ }^{29}$

Nesse movimento, fazia representações de si por meio de comparações com outros letrados que tematizaram o sertáo:

(...) Naturalmente você vai me falar de Euclides da Cunha. Mas Euclides foi um estudioso, um cientista. O sertáo está em sua obra como uma rosa num livro de botânica. E a alma do povo?

\footnotetext{
${ }^{28}$ CEARENSE, Catulo da Paixão. Em caminho do sertão. In: CEARENSE, Catulo da Paixão. Meu sertão, op. cit., p. 26.

${ }^{29}$ Em entrevista a Joel Silveira. Em: BARBOSA, Francisco de Assis; SILVEIRA, Joel. Os homens não falam de mais, op. cit., p. 192.
} 
E o povo vivendo? O povo como ele é, e não como a gente quer que ele seja. Abra um livro meu: lá está o povo cantando e sofrendo, o sertanejo vivo dentro do seu "habitat". 30

Aqui a citação é explícita. Catulo é a expressão da alma, ele é o “intérprete” do sertão. Mas como interpretar algo que não conhece? $\mathrm{O}$ autor tem sua própria resposta: a alma. Se Euclides conheceu o sertão, viu com os próprios olhos, Catulo deixa falar em si a alma do povo. Seu texto não é só representação de um ausente é, também, a apresentação da representação em si, é a própria expressão da coisa, que só é possível porque Catulo não inventa: ele a incorpora em seu momento de escrita.

A escolha pelo caminho que melhor levava a uma aceitação passava, inclusive, pela construção de poemas que visavam, por meio de metáforas, a conduzir e regrar a leitura do impresso de modo a compreender quem é aquele que escreve; de construir, no texto, uma representação de si, distinta da de seus personagens. No texto de $O$ sonho, que é uma espécie de apresentaçáo do livro feita por Catulo, ele se dirige a outros poetas para contar-lhes um sonho que tivera:

Poetas! Vou contar-vos um sonho, em que, n'um surto espiritual, me transportei ao sertão, onde nasci. A noite era de plenilúnio. Bebendo os mistérios da lua pelas mãos da saudade dos 25 anos de ausência ali, nos regaço dos Mattos indomesticados, entrei a cantar os versos que escrevi a essa Virgem Maria dos trovadores. Sentia-me opulento, mil vezes milionário, porque me encontrava, outra vez, no coração do meu palco de folhas. E cantava: “- Não há, ó gente, oh, não, luar, como esse do sertão", — quando um velho jequitibá, onde outrora me encostava para conversar com os pássaros errantes começou a falar assim:

"Quem te deu o direito de violar o silêncio desta noite misericordiosa?! Que vens aqui fazer nestas soledades, onde depois de teres sido confidente de nossos melindres, já fostes amaldiçoados pelos nossos coraçóes?! Não nos pertences mais. O teu estro está eivado de civilização. (...) Fita a lua. O seu brial enturvou-se. Como agradercer-te as estrofes que lhe fizeste, se as oferecestes à maldita civilização?’31

Catulo construía sua própria representação de maneira a desconstruir uma outra, que o via como um próprio homem da natureza, receita esta que o retiraria a identificação de poeta. A coincidência de seu nome com a de seus personagens teria de ser negada. Não foi, portanto, gratuito o aparecimento de uma explicação no começo do livro. Era a tentativa de regrar uma leitura que, Catulo sabia, poderia enveredar pelos caminhos da crítica produzida por Monteiro Lobato. Sem o conhecimento dessa crítica seria incompreensível entender como alguém que se avultava como poeta sertanejo introduzia seu livro exatamente com a representação oposta de si, ou seja, como alguém que era odiado pela natureza do sertáo, representado, no texto, pela fala do personagem de um velho jequitibá dirigindo-se a Catulo:

\footnotetext{
${ }^{30}$ Idem.

${ }^{31}$ CEARENSE, Catulo da Paixão. Sertão em flor, op. cit., p. 1. 
A manhã vai despertar e é conveniente que ela não te encontre aqui, sob a proteção dos meus ramos! A alvorada do sertão te odeia

Nunca te lembrar-te dela, que tanto te inspirava! Ela está enciumada! Cantaste a noite de luar e esqueceste-a! Vai, miserável! ${ }^{32}$

Essa representação visava a afastar o nome de Catulo da identificação como um sertanejo - que, lembremos novamente, de acordo com Mário de Alencar, era uma identidade que não faria do autor um poeta. No entanto, se, de um lado, o autor buscava afastar-se do sertão, por outro, a cidade ainda era encarada como sendo arredia a seus poemas. $\mathrm{O}$ círculo se fecha. Assim, ainda em $O$ sonho, é o velho jequitibá que, ao interrogar o poeta, sinaliza para o leitor como este deveria entender ser o lugar de Catulo:

Porque não nos oferecestes o livro que publicaste, como era do teu dever e gratidão?! Os poetas e os literatos de lá te consideram um reles modinheiro, um capadócio de insípidas serenatas! Fomos vingados!

Se estivesses entre nós, serias um sabiá honorário, e o teu livro já teria sido laureado pelos aplausos de toda a Natureza! ${ }^{33}$

Todo esse contorcionismo tornava-se necessário, antes de tudo, para fazer frente às críticas acerca de sua representação do sertão e do sertanejo. Essa receita era tanto mais importante porque avultavam, no mesmo período, outras obras que buscavam uma representação verossimilhante do sertão. E essa verossimilhança era imprescindível, uma vez que não se buscava, nessas obras com temáticas sertanejas, apenas a invenção deliberada do autor, mas, por uma conveniência histórica, a necessidade de conhecer o sertão como modo de entender a nação. Esse tema era instransponível naqueles idos e tornou-se, inclusive, algo necessário para se definir aquilo entendido no rol de "literatura nacional".

Assim, a recepção positiva das primeiras obras contendo os poemas sertanejos de Catulo reafirmou uma predileção por temáticas sertanejas no universo de leitores do período.

\section{A autoria como tradução}

Entusiasmado com o sucesso de vendas - alavancado também pela polêmica causada em torno da representação de um linguajar sertanejo na obra de Catulo —, o editor Castilho apostou em novas publicaçóes cujo tema "sertão" fosse o mote. Já em 1921, outra publicação

\footnotetext{
${ }^{32}$ Ibidem, p. 3.

${ }^{33}$ Ibidem, p. 4.
} 
foi esgotada em sua primeira edição. Tratava-se da obra Cantadores, a primeira publicação do folclorista Leonardo Motta e que veio à luz sob o selo da Livraria Castilho, a mesma de Catulo Cearense. Leonardo Motta vinha do Ceará trazendo na bagagem os resultados de suas pesquisas sobre os "cantadores do norte". Castilho, seguindo a mesma fórmula usada nas publicaçóes dos livros do autor de Meu sertão, fez aparecer várias opinióes abalizadas no texto de Motta, a fim de apresentá-lo ao grande público. O resultado foi uma primeira edição com dez mil exemplares esgotados em pouco tempo e que confirmaram o tino de Antônio Castilho.

À diferença dos livros de Catulo, Mota era apresentado como um autor que escrevia o que viu e viveu. $\mathrm{O}$ recurso à alma desaparece do discurso e o recurso da autópsia é evocado como o argumento de autoridade. Mas, ainda aqui, era traçada uma diferenciação com outras produçóes próximas às dele. De Afonso Arinos, a diferença é essa proximidade que fazia Mota ver melhor do que ninguém:

Leonardo Motta é o confidente da grande alma poética do sertanejo cearense. Ele não é um esteta como Arinos, que amava essas cousas à distância, que tinha todos os entusiasmos possíveis pelas nossas tradiçóes e pelas nossas lendas, mas não passava de um boulevardier incorrigível. (...)

Leonardo Motta, não. Tudo o que ele sabe é porque viu e porque viveu, porque se compraz nisso com um carinho que chega ao sacríficio de si mesmo, porque esteve ao lado de nosso homem rústico, intimamente, não como um viajante apressado, mas como um amigo, um camarada, um irmão, misturado com ele, integralizado no seu pensamento e nos seus sentimentos mais íntimos. ${ }^{34}$

Se essa aproximação íntima com o sertanejo fazia Leonardo Motta ser considerado autoridade para representar o sertão no mundo letrado, a falta dessa aproximação resultava, naqueles que não a tinham, o recurso a constantes exageros. O escritor e crítico José Américo de Almeida faz dessa comparação com outros escritores do sertáo o seu parâmetro para representar Leonardo Motta. Nela aparece o inevitável nome de Catulo:

Juvenal Galeno, Hermínio Castello Branco e Catulo Cearense, cada qual com o seu feitio, afinam entre nós as suas liras pelas trovas do sertão — o último com um deleitoso poder de imagens. Mas todos eles incidem em exageros que prejudicam, às mais das vezes, a naturalidade de suas composiçóes, ora elevando a forma acima da média intelectual dos cantadores, ora deprimindo-a a uma algaravia, com preocupaçóes dialetais, estranhas aos modismos populares. ${ }^{35}$

\footnotetext{
${ }^{34}$ Opinião do jornalista Aníbal Fernandes, que o editor Castilho fez incluir ao final do livro "Cantadores". In: MOTTA, Leonardo. Cantadores: poesia e linguagem do sertão cearense. Rio de Janeiro: Livraria Castilho, 1921, p. 391.

${ }^{35}$ Trecho de um artigo do escritor José Américo de Almeida, publicado no jornal O Norte, da Paraíba, que o editor Castilho fez incluir ao final do livro Cantadores. In: MOTTA, Leonardo. Cantadores: poesia e linguagem do sertão cearense. Rio de Janeiro: Livraria Castilho, 1921, p. 391.
} 
As reiteradas lutas acerca da melhor maneira de representar o homem do sertáo faziam com que diversas produçôes buscassem, cada qual mobilizando suas respectivas estratégias, a autoridade final para expressar o sertão e o sertanejo em seus textos. Ademais, essa tarefa mesclava-se com um caráter político de conhecer melhor o sertão para melhor conhecer a nação. Se, seguramente, essa agenda não esteve tão claramente expressa nas primeiras produçôes sertanejas de Catulo, não é possível desdenhar que o sucesso (e a quantidade) de temáticas sertanejas na literatura do período fosse resultado dessa agenda essencialmente política e que essa mesma agenda tornou-se absolutamente um tema incontornável para aqueles que buscavam, para as suas respectivas produçóes, o status de nacional que os garantisse um lugar na literatura do período. Afinal, a construçáo da literatura brasileira se pautou historicamente pela regra de que ela deveria ser "brasileira antes de ser literatura". Tal é o lugar de Catulo.

A grande tensão que perpassa essas produçóes é a incômoda questão de como representar melhor o sertão. Se, por um lado, a voz autorizada da ciência era vista como uma dentre as tradutoras mais abalizadas desse empreendimento, alguns nomes da literatura, que desde o século XIX construíam esse status, buscaram suas próprias estratégias de construção de autoridade.

Participando desse lugar de produção textual, Catulo da Paixão Cearense evocou a alma, como um terceiro elemento entre o poeta e a coisa, e buscou, a partir dessa tensão, a consolidação de seu nome dentro do panteão da literatura do período. Esse espaço só pôde ser buscado a partir de um diálogo tenso com outras representaçôes que também se faziam no período e que faziam, elas mesmas, suas estratégias, de forma a dar verossimilhança ao que se contava nos livros. Tais lutas de representaçôes são perceptíveis nas publicaçóes produzidas e só podem ser compreendidas se for levado em conta o caráter múltiplo e imprevisível das escolhas levadas pelos agentes que fizeram o espaço de produção textual da época.

Esse consórcio entre poeta e alma na obra de Catulo teve seu lugar central em 1928, com a publicação do volume de poesias, alvissareiramente intitulada de Alma do sertão, pela livraria editora Leite Ribeiro. A publicação divide-se em duas partes: uma com desafios sertanejos, onde o autor repetia a fórmula consagrada em seus livros anteriores, reproduzir a fala sertaneja em poemas sertanejos; e outra que constava de reflexóes em prosa acerca da mulher, em julgamentos de personagens de diversos tipos, tais como o operário, o anarquista e o mineiro.

O escritor Mário José de Almeida escreveu o prefácio sob o título de "Algumas notas sobre o ocupante da cadeira quarenta e um", numa clara alusão à Academia Brasileira de Letras, que, por sua vez, tinha quarenta cadeiras de "imortais" da literatura do país. Apresentando-o como o ocupante de tal cadeira de número 41 e como um dentre aqueles imortais, Mário fala dos versos de Catulo: "No verso, Catulo tem a expressão, que é um 'trouvaille', da sua singularíssima inteligência e uma interpretação do sentimento humano que ainda não encontrei em outros poetas."36

\footnotetext{
${ }^{36}$ ALMEIDA, Mário José de. Algumas notas sobre o occupante da cadeira quarenta-e-um. In: CEARENSE,
} 
"Interpretação do sentimento humano." É novamente como tradutor que Catulo é apresentado. Não que isso o retirasse sua genialidade, que aqui está ligada a um "trouvaille", um encontro - requisito para a expressão traduzida do sertanejo em seus versos no texto. Mário avança na explicação de sua apresentação-representação de Catulo a partir dos versos de seus Desafios: “(...) Estes Desafios são feitos no seu ritmo predileto. Alguns são variantes do folclore, e ganham brilho na oficina de Catulo, como as anedotas, também produçóes do povo, revivem na arte de contar de Humberto de Campos." 37

Representação que garante a Catulo seu reconhecimento como poeta a partir da expressão de um sertanejo que ele traduz. De um encontro que o torna genial por não vir de um trabalho de "virtude dos prosadores que é a paciência de Renan, de Flaubert, de Anatole de France", mas que, por essa falta mesmo de virtude, o transformaria, afinal, em alguém com uma "ingenuidade genial". 38

Aqui cabe uma reflexão. O exercício da tradução é muitas vezes entendido como uma impossibilidade de partida. A necessidade de "levar o leitor ao autor" e, ao contrário, "levar o autor ao leitor", compreenderia uma aporia inescapável, onde algo sempre se perderia nessa transiçáo. Traduzir aí seria servir a dois mestres: o estrangeiro em sua obra e o leitor em seu desejo de apropriação, onde o desejo de apropriação seria, ele mesmo, configurado numa traição à obra.

No entanto, é nessa própria incapacidade de traduzir de maneira "correta" o escrito ou a fala de um outro que o papel do tradutor, dessa figura num lugar equidistante entre o "autor-primeiro" e o leitor, é (ou deveria ser) lido, para o filósofo Paul Ricouer, como um trabalho de criação. A partir daí, o filósofo sugere a saída pelo abandono dos dois polos traduzível versus intraduzivel e uma aceitação do luto, que resultaria num ganho: “(...) o sonho da tradução perfeita equivale ao desejo de um ganho para a tradução, de um ganho que seria sem perda. É justamente desse ganho sem perda que é preciso fazer o luto até a aceitação da diferença incontornável do próprio e do estrangeiro."39

Essa aceitação do luto está intrinsecamente ligada, penso, às estratégias empreendidas por Catulo na construção de um espaço distinto para sua autoridade. Distinto, pois abriu um caminho possível no rol de escolhas postas pelo campo literário brasileiro daqueles tempos. O ganho na tarefa de tradução da língua sertaneja por Catulo é exatamente a possibilidade de criação que reside na representação do sertanejo e do seu linguajar exatamente no momento em que o cria. $\mathrm{O}$ ausente que fala na escrita dos poemas de Catulo é a representação de um tempo (o tempo do sertanejo, da "alma popular") que corrobora a autoridade da sua escrita, ou, dito de uma outra forma, na alma que escreve por Catulo reside não só o anonimato necessário para a autoridade do nome de Catulo como um conhecedor do

Catulo da Paixão. Alma do sertão. Rio de Janeiro: Livraria e Editora Leite Ribeiro, 1928, p. 21.

${ }^{37}$ Ibidem, p. 21.

${ }^{38}$ Ibidem, p. 21-23.

${ }^{39}$ RICOUER, Paul. Sobre a tradução. Belo Horizonte: UFMG, 2011, p. 29. 
"popular", mas, sobretudo, guarda a distância que torna possível o poeta urbano e letrado Catulo alçar-se como autor de um tempo distante, com o qual não se confunde. A alma é o tempo que ao falar vai construindo a autoria de Catulo, ao passo que o resguarda de ser identificado com o seu personagem. Só através dela é possível o encontro de temporalidades distintas num só indivíduo que ao escrevê-las, as cria. A autoria se faz num tempo e com o tempo, ela é sujeito da escrita e, ao mesmo tempo, objeto dela.

A imagem de um poeta "do sertanejo" distante do sertáo só pode ser entendida a partir da representação mesma que Catulo cria no texto. É pela representaçáo produzida no texto que o leitor pode medir a distância daquele que escreve diante daquele que é representado em personagem e, só aí, como Catulo queria, entendê-lo como um poeta “do sertanejo", mas não sertanejo.

O texto de Catulo é a representação em suas duas dimensóes: é transitiva, pois que representa algo (o sertanejo), e reflexiva, pois que se apresenta representando alguma coisa (o texto apresenta o próprio sertanejo). Coloca-se como uma tentativa de traduçáo e criação. Em Catulo, a criação dá um sentido à representação e não só a mostra tal como é a coisa que busca representar ou, como bem salienta Jacques Le Brun: "O texto é o sinal de um acontecimento que ele não é capaz de dizer. Ele apenas diz que um acontecimento teve lugar, descreve o que foi feito desse acontecimento, como um sentido cristalizou nele (...).”º

Em Catulo há a reivindicação da escrita como representação abalizada de um ausente, mas, sobretudo, há uma apresentação de uma criação possível a partir do trabalho de tradução, onde a autoridade do tradutor só pode ser compreendida pela análise da historicidade das práticas de escrita dadas no tempo. A perspicácia em apresentar Catulo como alguém por onde um Outro fala é a estratégia final nesse jogo de representaçôes, que cria aquele que escreve, de forma a entregar, por meio de diversos artifícios de construção de autoridade, a condição de poeta a este último.

\section{Fontes primárias}

ALENCAR, Mário de. A poesia de Catulo. In: CEARENSE, Catulo da Paixão. Sertão em flor. Rio de Janeiro: Livraria Castilho, 1919.

BARBOSA, Francisco de Assis; SILVEIRA, Joel. Os homens não falam de mais. Rio de Janeiro: Editora Alba, 1942.

CAMPOS, Humberto de. Homenagem a Catulo Cearense. In: CEARENSE, Catulo da Paixão. Meu sertão. Rio de Janeiro: Livraria Castilho, 1918.

CEARENSE, Catulo da Paixão. Alma do sertão. Rio de Janeiro: Livraria e Editora Leite Ribeiro, 1928.

\footnotetext{
${ }^{40}$ LE BRUN, Jacques. Da crítica textual à leitura do texto. Projeto História, São Paulo, n. 17, p. 45-54, nov. 1990.
} 
. Matta illuminada. Rio de Janeiro: Livraria Castilho, 1924.

. Meu sertão. Rio de Janeiro: Livraria Castilho, 1918.

. Sertão em flor. Rio de Janeiro: Livraria Castilho, 1919.

D’OLIVEIRA, Alberto. Catulo Cearense. In: CEARENSE, Catulo da Paixão. Meu sertão. Rio de Janeiro: Livraria Castilho, 1918.

O País. 12 set. 1918.

O País. 25 fev. 1906.

MOTTA, Leonardo. Cantadores: poesia e linguagem do sertão cearense. Rio de Janeiro: Livraria Castilho, 1921.

\section{Referências bibliográficas}

BAPTISTA, Abel Barros. A formação do nome. Campinas: Editora Unicamp, 2003.

. O livro agreste. Campinas: Unicamp, 2005.

CERTEAU, Michel de. La Fabula Mistica. Siglos XVI-XVII. México: Universidad Iberoamericana, 2004.

CHARTIER, Roger. A ordem dos livros. Brasília: UNB, 1996.

. Autoria e história cultural da ciência. Rio de Janeiro: Azougue Editorial, 2013.

. O que é um autor: revisão de uma genealogia. São Carlos: Ufscar, 2012.

FOUCAULT, Michel. O que é um autor? In: FOUCAULT, Michel. Ditos e escritos. Estética: literatura e pintura, música e cinema. Rio de Janeiro: Forense Universitária, 2009, v. III.

FRANCHETTI, Paulo. Estudos de Literatura brasileira e portuguesa. Cotia: Ateliê Editorial, 2007.

HANSEN, João Adolfo. Autor. In: JOBIM, José Luís (Org.). Palavras da crítica. Rio de Janeiro: Imago, 1993.

. Reorientaçóes no campo da leitura literária. In: ABREU, Márcia; SCHAPOCHNIK, Nelson (Orgs.). Cultura letrada no Brasil: objeto e práticas. Campinas: Mercado de Letras, ALB/São Paulo: Fapesp, 2005.

LE BRUN, Jacques. Da crítica textual à leitura do texto. Projeto História, São Paulo, n. 17, p. 45-54, nov. 1990.

LIMA, Nísia Trindade. Um sertão chamado Brasil. Rio de Janeiro: Revan: Iuperj/Ucam, 1999.

PÉCORA, Alcir. Máquina de gêneros. São Paulo: Edusp, 2001. 
RICOUER, Paul. Sobre a tradução. Belo Horizonte: UFMG, 2011, p. 29.

VIANNA, Hermano. O mistério do samba. Rio de Janeiro: Zahar/Ed. UFRJ, 2010.

WOODMANSEE, Martha. On the author effect: recovering collectivity. In: WOODMANSEE, Martha; JASZI, Peter (Ed.). The Construction of Authorship. Textual Appropriation in Law and Literature. Durham e London: Duke University Press, 1994, p. $15-28$.

. The Genius and the Copyright: Economic and Legal Conditions of the Emergence of the Author. Eighteenth-Century Studies, v. 17, n. 4, p. 425-448, 1984. 